\title{
PERFORMANCE EVALUATION OF A MOTORISED PALM OIL EXTRACTOR WITH QUALITY ASSESSMENT OF THE PALM OIL EXTRACTED IN COMPARISON WITH A MANUAL VERTICAL PRESS
}

\section{NICHOLAS KIGGUNDU* and JOSEPH JJAGWE*}

\begin{abstract}
Traditional methods of palm oil extraction from palm fruits (Elaeis guineensis) produce low quality and quantity of oil. This study sought to design, construct and test a motorised palm oil extractor with evaluation of the oil extracted in comparison with a manual vertical press. The performance parameters tested were oil extraction ratio (OER), oil extraction efficiency (OEE), machine discharge efficiency (MDE) and oil extraction losses (OEL) while the tested physio-chemical parameters were free fatty acids (FFA), iodine value (IV), saponification value (SV) and peroxide value (PV). There were significant differences $(p \leq 0.05)$ in OER (16.20\% and $13.53 \%)$, OEE (77.13\% and $64.44 \%)$ and OEL (18.30\% and $24.76 \%)$ while the MDE (81.70\% and $73.13 \%$ ) were not significantly different $(p>0.05)$ for the motorised and vertical press, respectively. No significant differences were observed for IV and SV while FFA showed significant differences $(p \leq 0.05)$. The $P V$ was not detected for both methods. A motorised palm oil extractor produced oil of higher quality and had higher performance efficiencies as compared to the manual vertical press. The novelty of this work was in producing an efficient equipment that is affordable to a smallholder farmer which extracts palm oil of high quality.
\end{abstract}

Keywords: palm oil, quality parameters, screw press, efficiency, extraction.

Received: 31 May 2019; Accepted: 14 February 2020; Published online: 4 November 2020.

\section{INTRODUCTION}

Oil palm (Elaeis guineensis) originated from the tropical rain forest region of West Africa (Azodo et al., 2013; Poku, 2002). Oil palm grows mainly in tropical climates (Razali et al., 2012) and due to its economic importance as a high yielding source of edible oil, it is grown as a plantation crop in most countries with tropical climates (Poku, 2002). In 2003,

\footnotetext{
Department of Agricultural and Biosystems Engineering, School of Food Technology Nutrition and Bio-Engineering, College of Agricultural and Environmental Sciences, Makerere University, P.O. Box 7062, Kampala, Uganda.

E-mail: kiggundu@caes.mak.ac.ug
}

the government of Uganda with BIDCO Uganda Limited, signed an agreement to undertake the oil palm project at Bugala Islands Kalangala district. All plantation related activities and the extraction of crude oil from the fresh fruit bunches was managed by the Oil Palm Uganda limited (OPUL). IFAD (2010) reported that there were 10088 ha of oil plantation with 1600 ha under smallholders.

Oil palm produces two types of oils; palm oil and palm kernel oil (Azodo et al., 2013). Most oils are recovered from oil bearing crops by cooking, grinding, expelling, pressing by chemical methods or solvent extraction of the raw materials (Anebi et al., 2014). Small scale processors mainly in 
developing countries extract their oils traditionally by use of a constructed vertical press that is operated by about three to four workers (Figure 1). The commonest method of extracting oil from oilseeds is the mechanical pressing method which may be hydraulic press or screw press principle (Moses, 2014). Presses that have been developed over the years include manual vertical screw press, motorjack press, spindle press, hydraulic press, and the combined screw/hydraulic press (Figure 2). The screw press principle is more reliable, has a higher efficiency and usually more adaptable for small and medium scale producers (Olaniyan et al., 2012) than the hydraulic press which is otherwise more expensive, need more maintenance, requires more labour and involves risking contamination of the oil with poisonous hydraulic fluid (Aremu and Ogunlade, 2013; Olaniyan et al., 2012).

The oil extracted from oil palm is commonly referred to as crude palm oil (CPO) because it is not refined. In most developing countries, most of the $\mathrm{CPO}$ produced by small scale processors does not meet the quality standards for industrial use mainly due to presence of high levels of free fatty acids (Osei-Amponsah et al., 2012). In this regard, non-industrial $\mathrm{CPO}$ must fulfill the requirements of quality applicable to all oils and fats as their consumption can be harmful to human beings due to presence of components that can trigger reactions that lead to degradation of these oils (Ngando et al., 2011). The quality of vegetable oils varies with the quality of the fruits, the method of processing, handling and storage used (Ohimain et al., 2013; Okogeri and Otika, 2014) and according to Ngando et al. (2011) and Kukeera et al. (2015), the mostly examined quality parameters include moisture content, iodine value (IV), peroxide value $(\mathrm{PV})$, saponification value (SV) and free fatty acids (FFA). The presence of FFA indicates the initiation of acidification and quality deterioration of an oil sample (Ngando et al., 2013) as well as indicating its degree of hydrolysis (Tarmizi et al., 2016). The IV is an index for the adulteration of oils as it measures the unsaturation levels of the oil while the PV is the measure of the degree of oil oxidation giving an indication of the levels of primary lipid oxidation, quality and stability of fats and oils (Agbaire, 2012). SV indicates the molecular weights of triglycerides and it is inversely proportional to the length of fatty acids (Agbaire, 2012).
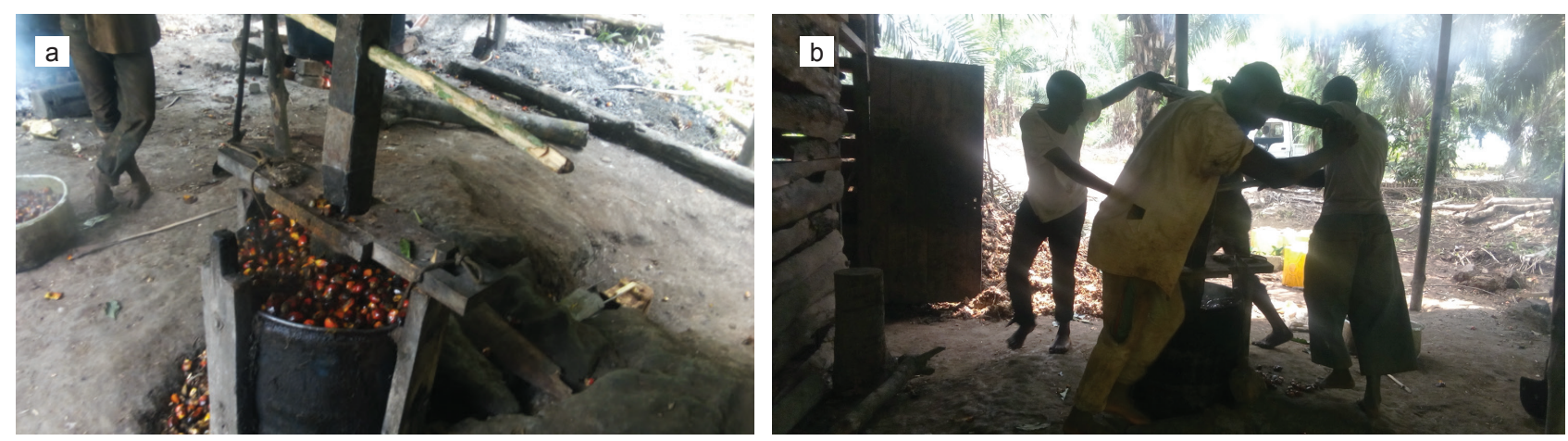

Source: Photos courtesy of Jjagwe, J.

Figure 1. Traditional method of oil extraction used in Buwama-Uganda: (a) manual vertical press with digested oil palm fruits ready for extraction and $(b)$ workers extracting oil manually.
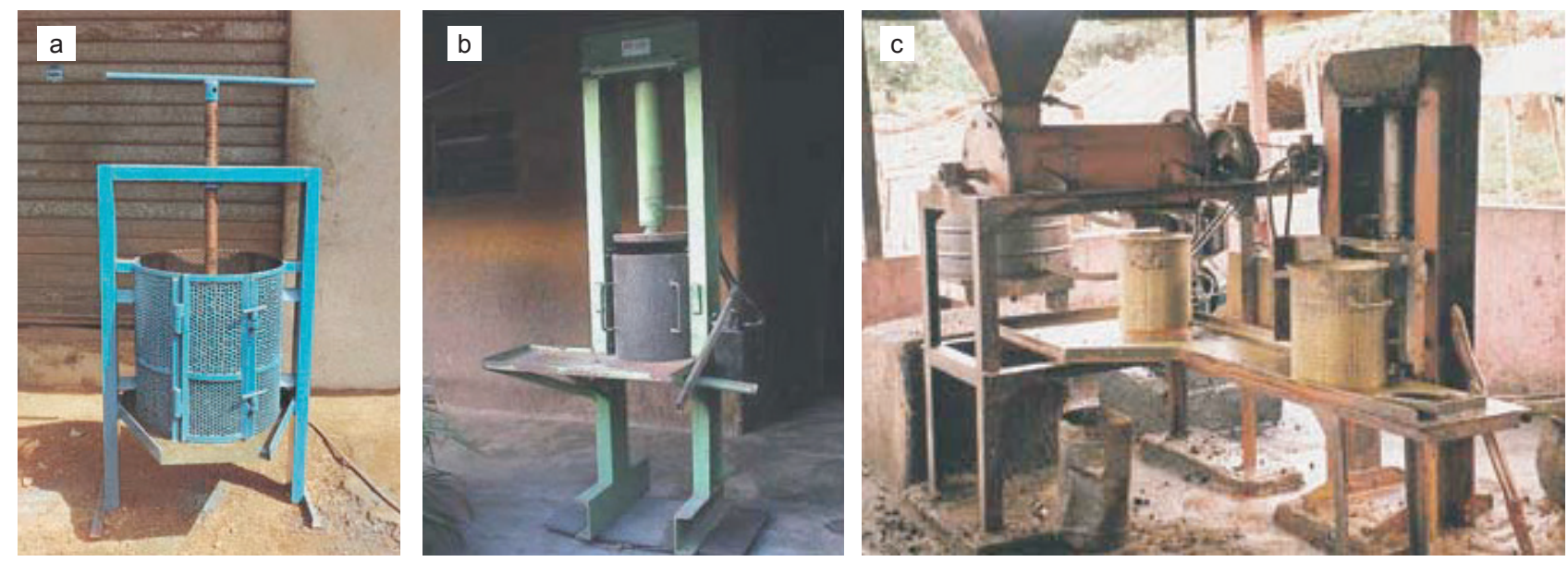

Figure 2. Commonly used presses for oil extraction: (a) spindle press, (b) hydraulic press and (c) combined screw and hydraulic press (Poku, 2002). 
There is a need to increase the supply of palm oil for meeting the food security needs of the world (Mahmud et al., 2010) since the demand for palm oil is not only growing in the food sector but also in industries where it is used for product development like cosmetics and soaps (Nsiah et al., 2012). In SubSaharan Africa, advances in agricultural productivity have been hindered by low technology and therefore the development of new technologies will work towards changing the optimal size of production in favour of large holdings (Aremu and Ogunlade, 2013). The novelty of this study is justified by the fact that most of the knowledge related to the design and development of screw press equipment belongs to the holders of large manufacturers in industrial scale production systems (Olaniyan et al., 2012). Besides, these screw presses are not available on the Ugandan market and hence are just imported by the large-scale oil extraction companies. Therefore with an increased number of small scale holders of oil palm farms in Uganda, there is a need to develop technology that will be affordable to the small producers to meet the demand of palm oil that is projected to increase to 60 million tonnes per year by 2020 from the current 46 million tonnes per year (World Growth, 2011) as well as increasing incomes to the small scale farmers. The objective of this work was to design and construct a low scale motorised extractor to effectively extract palm oil at an affordable price while maintaining quality, thus the screw press principle was adopted in designing and constructing a palm oil extractor to effectively extract palm oil from the digested palm fruits.

\section{MATERIALS AND METHODS}

\section{Design Considerations}

In the design of the machine, key considerations made included high oil yield, high oil extraction efficiency and ratio, low extraction loss, availability and cost of construction materials. Other considerations included the simplicity in design and ease to fabricate the machine, usability of the machine without previous technical training, a strong frame to ensure structural stability and strong support for the machine, and ability to easily dismantle the machine for cleaning purposes.

\section{Design Concept}

The machine consisted of four major components; the feeding component, extraction component, power component and the frame. The feeding component consisted of the hopper; the extraction component consisted of the worm screw shaft, the perforated frustum barrel (squeezing chamber) and both the oil and residual outlets; the power component consisted of the prime mover (geared motor) and the chain while the frame served as a stand for the machine on which all other components were mounted. The worm screw shaft rotates in the perforated barrel and conveys the digested fruits from the feeding section towards the discharge section where there are outlets for both the cake and the extracted oil. All the components in contact with the fruits were made out of stainless steel because it is the recommended standard material for edible food materials. Pressure was achieved in the machine by the operation of the tapered worm shaft which was designed as a step-down volume from the feed end towards the discharge end, thus, reducing the area available for the fruits and increasing pressure to efficiently extract the oil.

\section{Design and Selection of the Shaft}

The worm shaft is the main component of the screw press and is acted upon by weights of material being processed (sprocket and screw threads). In operation, the worm shaft with the aid of screw threads conveys, presses and squeezes the material (digested palm fruits) for oil extraction. Therefore, in order to safeguard against bending and tensional stresses, the diameter of the shaft was determined from Equation (1) as given by Mrema and McNulty (1985).

$$
d_{S}=\sqrt[3]{\frac{P}{N}} \times 112
$$

Equation (1)

where; $d_{s}$ - diameter of the shaft in mm, $P$ - power rating of the motor in $\mathrm{kW}, \mathrm{N}$ - rotational speed of the shaft in rpm. Working with what was available in the workshop, a geared motor (Figure 3) of $0.75 \mathrm{~kW}$ was available and in order to effectively squeeze the fruits, a speed of $120 \mathrm{rpm}$ was taken, therefore substituting for $\mathrm{P}=0.75 \mathrm{~kW}$ and $\mathrm{N}=120 \mathrm{rpm}$ into Equation (1) $d_{s}=20.6 \mathrm{~mm}$, therefore a stainless steel rod of $20 \mathrm{~mm}$ was selected for the worm shaft.

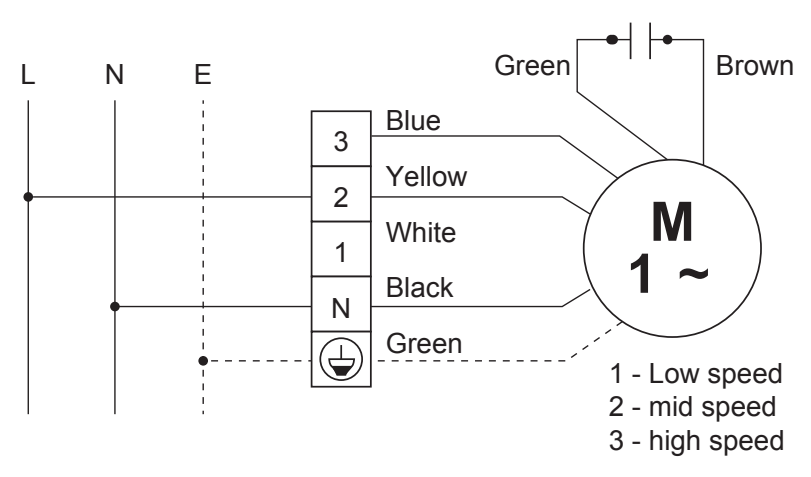

Source: https: / / www.fantech.com.au/images / PDF/Catalogue/ WiringDiag.pdf

Figure 3. Wiring schematic of a single phase motor. 


\section{Design of the Screw Threads}

The worm shaft is essentially a tapered screw conveyor with the volumetric displacement being decreased from the feed end of the barrel to the discharge end. The screw threading system was designed with aid of stainless steel rods of $6 \mathrm{~mm}$ thickness welded onto the shaft with a decrease in the pitch and depth towards the discharge end using Equation (2) as given by Shigley and Mischeke (2001).

$$
U_{n}=a+(n-1) d
$$

Equation (2)

where; $U_{n}$ - screw depth at the discharge end in $\mathrm{mm}$, $a$ - screw depth at the feed end in $\mathrm{mm}, d$-common difference between the next successive screw depths (decrease in pitch) and $n$ - number of turns. Depending on the mass of the fruits that was desired to be processed per given time within the working chamber of the designed volume, $\mathrm{a}=110 \mathrm{~mm}$ and depending on the mean diameter of the kernel, $\mathrm{U}_{\mathrm{n}}=35 \mathrm{~mm}$ a decrease in pitch $(d)$ of $10 \mathrm{~mm}$ was taken hence designing a screw thread with 8 turns.

\section{Design of the Working Chamber}

The working chamber (squeezing section) was designed based on the configuration of the screw thread that was to rotate within it. This working chamber was designed as a frustum from stainless steel sieve of $3 \mathrm{~mm}$ thickness and with perforations of $2 \mathrm{~mm}$ and its volume was determined from Equation (3).

$$
V=\frac{\pi h}{3}\left(R^{3}+R r+r^{3}\right)
$$

Equation (3)

where; $V$ - volume of the frustum in $\mathrm{m}^{3}, h$ - height in $\mathrm{m}, r$ - radius at the lower end (discharge end) in $\mathrm{m}$, $R$ - radius at the upper base (feed in end) in m. Taking a clearance of $5 \mathrm{~mm}$ between the screw threads and the working chamber, $\mathrm{h}=0.44 \mathrm{~m}, \mathrm{R}=0.125 \mathrm{~m}, \mathrm{r}$ $=0.05 \mathrm{~m}$, therefore a frustum of volume $3.8373 \times 10^{-3}$ $\mathrm{m}^{3}$ was designed as the working chamber.

\section{Design of the Load Lifted by the Screw}

The load that can be lifted by the screw was determined from Equations (4), (5) and (6) as given by Hall et al. (1961).

$$
\begin{aligned}
& W_{e}=T \frac{(1-\mu \tan \theta \cos \alpha)}{\frac{D_{m}}{2}\left(\tan \theta+\frac{\mu}{\cos \alpha}\right)} \\
& T=\frac{P}{2 \pi N} \\
& \alpha=\tan ^{-1}\left(\tan \theta_{n} \cos \theta\right)
\end{aligned}
$$

Equation (4)

Equation (5)

Equation (6) where; $W_{e}$ - load lifted by the screw in N, T - torque transmitted by the screw shaft in $\mathrm{Nm}, D_{m}$ - mean thread diameter at the feed in end (a) in $m, \mu$ coefficient of friction, $\theta_{n}$ - thread angle in degrees and $\theta$ - tapering angle in degrees. Substituting $\mathrm{N}=2$ $\mathrm{rev} / \mathrm{s}, \mathrm{P}=750 \mathrm{~W}, \mathrm{~T}=59.68 \mathrm{Nm}, \mathrm{D}_{\mathrm{m}}=110 \mathrm{~mm}, \theta=5^{0}$, $\theta_{n}=15^{0}, \mu=0.15$ hence, $\alpha=14.98^{0} \mathrm{~W}_{\mathrm{e}}=60 \mathrm{~N}$ hence, $6 \mathrm{~kg}$ of digested fruits can be processed per unit time.

\section{Design of the Pressure to be Developed by the Screw Thread}

The pressing area and the pressure to be developed by the screw thread were determined by Equations (7) and (8) as given by Hall et al. (1961).

$$
\begin{array}{ll}
A_{P}=\pi D_{m} n U_{n} & \text { Equation (7) } \\
P_{r}=\frac{W_{e}}{A_{p}} & \text { Equation (8) }
\end{array}
$$

where; $P_{r}$ - pressure developed by the screw thread, $A_{p}$ - pressing area.

Substituting $\pi=3.142, \mathrm{D}_{\mathrm{m}}=110 \mathrm{~mm}, \mathrm{n}=8, \mathrm{U}_{\mathrm{n}}=$ $35 \mathrm{~mm}$ hence, $A_{p}=96774 \mathrm{~mm}^{2}$ and $P_{r}=3.1 \times 10^{-3}$ $\mathrm{Nmm}^{-2}$. Therefore, a pressure of $0.0031 \mathrm{MPa}$ would be available for pressing and squeezing oil from the digested fruits during operation.

\section{Design for the Pressure of the Working Chamber}

The pressure that can be withstood by the pressing chamber was determined by Equation (9) (Khurmi and Gupta, 2005).

$$
P_{b}=\frac{2 t \delta_{a}}{D_{i}}
$$

Equation (9)

where; $P_{b}$ - pressure to be withstood by the chamber in $\mathrm{Pa}, t$ - thickness of the chamber in $\mathrm{mm}, \delta_{a}$ allowed stress - 0.27 yield stress in $\mathrm{Nmm}^{-2}$ and $D_{i}$ - inside diameter of the chamber at the feed in end in $\mathrm{mm}$. The yield stress of stainless steel is given as $241 \mathrm{MPa}$ by Khurmi and Gupta (2005). Substituting $\mathrm{t}=3 \mathrm{~mm}, \delta_{a}=65.07 \mathrm{MPa}, \mathrm{D}_{\mathrm{i}}=260 \mathrm{~mm}$ hence $\mathrm{P}_{\mathrm{b}}=$ $1.5 \mathrm{Nmm}^{-2}$ or $1.5 \mathrm{MPa}$. This means that the pressure the working chamber can withstand $(1.5 \mathrm{MPa})$ is greater than the pressure developed by the screw press $(0.0031 \mathrm{MPa})$. Therefore, the chamber will withstand the extraction pressure without bursting.

\section{Design for the Capacity of the Screw Press}

The theoretical capacity of the expeller was determined using Equation (10) (Onwuala et al., 2006). 


$$
Q_{e}=\frac{\pi}{4}\left(D_{s}^{2}-d_{s}^{2}\right) P N_{s} \varphi \ell \quad \text { Equation (10) }
$$

where; $Q_{e}$ - theoretical capacity of the expeller in $\mathrm{kgh}^{-1}, D_{s}$ - diameter of the screw thread in $\mathrm{m}, d_{s}$ base diameter of the screw shaft in $\mathrm{m}, P_{s}$ - screw pitch at the feeding end in $\mathrm{m}, N_{s}$ - rotational speed of the screw shaft in $\mathrm{rpm}, \varphi$ - filling factor and $\ell$ bulk density of palm fruit in $\mathrm{kgm}^{-3}$. Substituting $\mathrm{D}_{\mathrm{s}}=130 \mathrm{~mm}, \mathrm{~d}_{\mathrm{s}}=20 \mathrm{~mm}, \mathrm{P}_{\mathrm{s}}=90 \mathrm{~mm}, \mathrm{~N}_{\mathrm{s}}=120 \mathrm{rpm}$, $\varphi=0.8$ and $\ell=913 \mathrm{~kg} \mathrm{~m}^{-3}$ into Equation (10) hence, $\mathrm{Q}_{\mathrm{e}}=102 \mathrm{kgh}^{-1}$.

\section{Testing the Machine Extraction Performance}

Palm fruits for the testing of the machine were obtained from BAK Ecological Farm located in Buwama Mpigi district (N0.02898, E32.06071), which close to the equator with consistent weather variables over the years. The annual rainfall of the area is about $1264 \mathrm{~mm}$ and average temperature is between $16^{\circ} \mathrm{C}-29^{\circ} \mathrm{C}$ (Wortmann and Sones, 2017). The soils are mainly Vertisols and Gleyic Arenosols which are often acidic with moderate levels of organic matter (Wortmann and Sones, 2017). Harvesting of palm fruits at the farm is done throughout the year after observing that fruit bunches are ripe and ready for harvesting. For experimental purposes, sampling of fruits was done in the months of January, March and May in 2016. On each sampling, fruits were grab sampled five times and then mixed to form a single composite sample that was used for oil extraction. The fruits were digested to rupture the oil containing cells and ease the process of oil extraction. Digestion was achieved by boiling thoroughly cleaned fruits from a stainless-steel saucepan on a cook stove using charcoal as the fuel at temperature ranges of $130^{\circ} \mathrm{C}-150^{\circ} \mathrm{C}$ for $2 \mathrm{hr}$. The machine was started and $6 \mathrm{~kg}$ of the digested fruits were continuously fed into the machine through the hopper every minute. Thus, the feeding rate of the machine was $360 \mathrm{~kg}$ $\mathrm{hr}^{-1}$ which was greater than the batch feeding rate of $200 \mathrm{~kg}$ per extraction time which varied between 1 $\mathrm{hr}$ and $1.5 \mathrm{hr}$ depending on the extraction efficiency of the workers. The screw press conveyed, squeezed and pressed the fed in fruits in order to extract the oil. The digested fruits fed in, the residual cake and the amount of oil extracted were collected and weighed separately and this was done in triplicates. The same parameters were taken in triplicates for the traditional extraction method that was being used in Buwama so that a quantitative performance analysis could be done with the two methods of oil extraction. The values obtained were used to calculate the oil yield (oil extraction ratio), oil extraction efficiency, machine discharge efficiency and oil extraction losses as by Equations (11), (12), (13) and (14) (Owalarafe et al., 2007).

$$
\begin{array}{ll}
O E R=\frac{M_{O E}}{M_{F F}} \times 100 & \text { Equation (11) } \\
O E E=\frac{O E R}{A E O} \times 100 & \text { Equation (12) } \\
M D E=\frac{M_{O E}+M_{R C}}{M_{F F}} \times 100 & \text { Equation (13) } \\
O E L=\frac{M_{F F}-\left(M_{O E}+M_{R C}\right)}{M_{F F}} \times 100 & \text { Equation (14) }
\end{array}
$$

where; OER - oil extraction ratio (\%), OEE - oil extraction efficiency (\%), MDE - material discharge efficiency (\%), OEL - oil extraction loss (\%), $\mathrm{M}_{\mathrm{OE}}$ mass of oil extracted $(\mathrm{kg}), \mathrm{M}_{\mathrm{FF}}$ - mass of fruits fed into the machine $(\mathrm{kg}), \mathrm{MRC}$ - mass of residue cake $(\mathrm{kg}), \mathrm{AEO}$ - amount of oil expected $(\mathrm{kg})$ which is $21 \%$ of $\mathrm{M}_{\mathrm{FF}}$ according to Razali et al. (2012).

\section{Physio-chemical Quality Analysis of the Extracted Oil Samples}

Oil samples as extracted using the two methods (motorised and traditional methods) were taken to the Food Analysis Laboratory of the Department of Food Science, Technology and Bio-engineering of Makerere University. The physio-chemical parameters that were analysed included FFA, PV, IV and SV. All the parameters were analysed in triplicates for each sample as extracted by each method.

\section{Determination of FFA}

FFA concentration was determined by first mixing $25 \mathrm{ml}$ of diethylether, $25 \mathrm{ml}$ alcohol, $1 \mathrm{ml}$ of phenolphthalein and neutralising this mixture with $0.1 \mathrm{M}$ sodium hydroxide and then adding $2 \mathrm{~g}$ of the oil sample to form an alcoholic solution of the oil (Pearson, 1976). The alcoholic oil solution was then titrated with aqueous $0.1 \mathrm{M}$ of sodium hydroxide using $1 \mathrm{ml}$ of phenolphthalein as the indicator with constant shaking until a pink persistent colour was obtained. This procedure was done for both the oil samples in triplicates and FFA was determined using Equation (15).

$$
F F A=\frac{\text { titration }(m l) \times 5.61}{w t}
$$

Equation (15)

where; FFA - free fatty acids (\% of oleic acid), wt weight of the oil sample $(\mathrm{g})$.

\section{Determination of PV}

The PV was determined by weighing accurately $3 \mathrm{~g}$ of the oil sample into a dry $250 \mathrm{ml}$ conical flask 
and then adding $10 \mathrm{ml}$ of chloroform, followed by $15 \mathrm{ml}$ of glacial acetic acid and $1 \mathrm{ml}$ of aqueous potassium iodide solution (Pearson, 1976). The flask was shaken for $1 \mathrm{~min}$ and after $75 \mathrm{ml}$ of water was added and the mixture $(\mathrm{V} \mathrm{ml})$ titrated with $0.01 \mathrm{M}$ sodium thiosulphate solution using soluble starch as the indicator. A reagent blank $\left(\mathrm{V}_{\mathrm{o}} \mathrm{ml}\right)$ oil sample determination was also carried out using the same procedure. The PV was determined using Equation (16).

$$
P V=\frac{\left(V-V_{\mathrm{o}}\right) \times 1000}{w t}
$$

Equation (16)

where; $P V$ - peroxide value $\left(\right.$ meq $\left.\mathrm{kg}^{-1}\right), V$ - sample titer (ml), $V_{o}$ - blank titer (ml), $T$ - molarity of sodium thiosulphate, $w t$ - weight of the oil sample (g).

\section{Determination of IV}

The IV was determined by weighing $2 \mathrm{~g}$ of the oil sample into a $250 \mathrm{ml}$ conical flask and then adding $10 \mathrm{ml}$ of carbon tetrachloride followed by $20 \mathrm{ml}$ of Wijs' solution and then allowing the mixture to stand in the dark for 30 min (Pearson, 1976). To the solution, $15 \mathrm{ml}$ of potassium iodide solution and $100 \mathrm{ml}$ of water were added and the mixture titrated with $0.1 \mathrm{M}$ thiosulphate solution using starch as the indicator just before the end point (a ml). A blank test of the oil sample was also carried out using the same procedure $(\mathrm{b} \mathrm{ml})$. The IV was determined from Equation (17).

$$
I V=\frac{(b-a) \times 1.269}{w t}
$$

Equation (17)

where $I V$ - iodine value, $b$ - blank titer (ml), $a$-sample titer (ml), wt - weight of the oil sample $(\mathrm{g})$.

\section{Determination of SV}

The SV was determined by weighing $2 \mathrm{~g}$ of the oil sample into a conical flask and adding 25 $\mathrm{ml}$ of alcoholic potassium hydroxide solution. The flask was then heated in boiling water for 1 hr with frequent shaking (Pearson, 1976). To the hot solution, $1 \mathrm{ml}$ of phenolphthalein solution was added and then titrated the hot excess alkali with $0.5 \mathrm{M}$ hydrochloric acid (a ml). A blank titration was also carried out at the same time $(\mathrm{b} \mathrm{ml})$. The SV was determined from Equation (18).

$$
S V=\frac{(b-a) \times 28.05}{w t}
$$

Equation (18)

where; $S V$ - saponification value, $a$ - sample titer $(\mathrm{ml}), b$ - blank titer (ml), wt - weight of the oil sample (g).

\section{Statistical Analysis}

Both the performance and oil quality parameters for each extraction method were determined in triplicates and the results were analysed with SPSS 16.0 to compare means with the independent samples T-test.

\section{RESULTS AND DISCUSSION}

\section{Production of the Machine Parts}

The stand was constructed of stainless steel angle lines of $40 \mathrm{~mm} \times 40 \mathrm{~mm}$ with a thickness of $3 \mathrm{~mm}$. Four pieces of $1122 \mathrm{~mm}$ were cut and bent at an angle of $30^{\circ}$ at a distance of $142 \mathrm{~mm}$ from the base to increase on the stability. These were welded together to form the stand. From the bent end, two pieces of angle lines of $459 \mathrm{~mm}$ were welded to form the motor seat. The hopper was made from a stainless steel sheet of $3 \mathrm{~mm}$ thickness and $300 \mathrm{~mm} \times 200 \mathrm{~mm}$ was bent to form the round hopper. A stainless-steel pipe of $35 \mathrm{~mm}$ diameter was welded on the machine to act as the oil outlet (Figure 4). The screw press was made by welding stainless round bars of $6 \mathrm{~mm}$ thickness onto the shaft, these were made at a depth of $220 \mathrm{~mm}$, $200 \mathrm{~mm}, 180 \mathrm{~mm}, 160 \mathrm{~mm}, 140 \mathrm{~mm}, 120 \mathrm{~mm}, 100 \mathrm{~mm}$ a

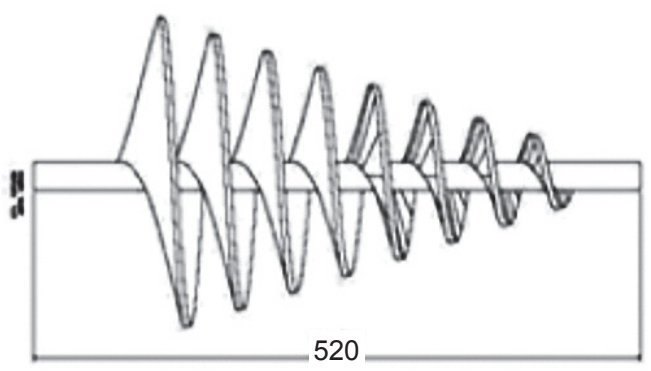

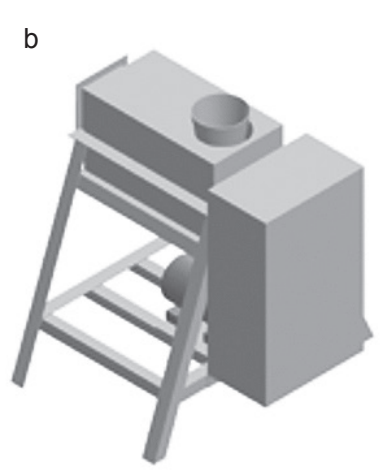

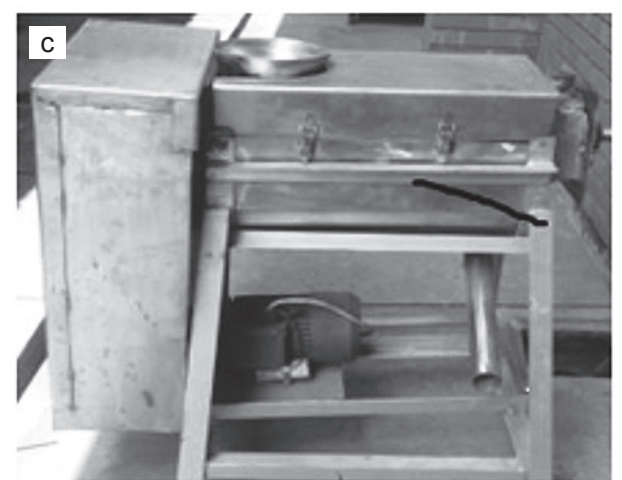

Figure 4. Machine components: (a) screw press, (b) computer aided designed machine and (c) fabricated machine. 
and $80 \mathrm{~mm}$ respectively to form the tapering screw thread with the feed in pitch at $90 \mathrm{~mm}$ and decreasing by $10 \mathrm{~mm}$ up to the discharge end. The pressing chamber was made from a stainless steel sieve of 3 $\mathrm{mm}$ thickness with uniform perforations of $2 \mathrm{~mm}$. This was bent using a bending machine to form a frustum of length $440 \mathrm{~mm}$, upper diameter (feeding end) of $260 \mathrm{~mm}$ and lower diameter (at discharge end) of $100 \mathrm{~mm}$. Production process included; marking out, cutting, drilling, machining, joining, fitting and fabrication. All the material components were made from stainless steel and welding done by stainless welding rods. The total production cost of the machine was USD 1142. The production drawings, part and materials list of the machine components are shown in Figures 5 and 6.

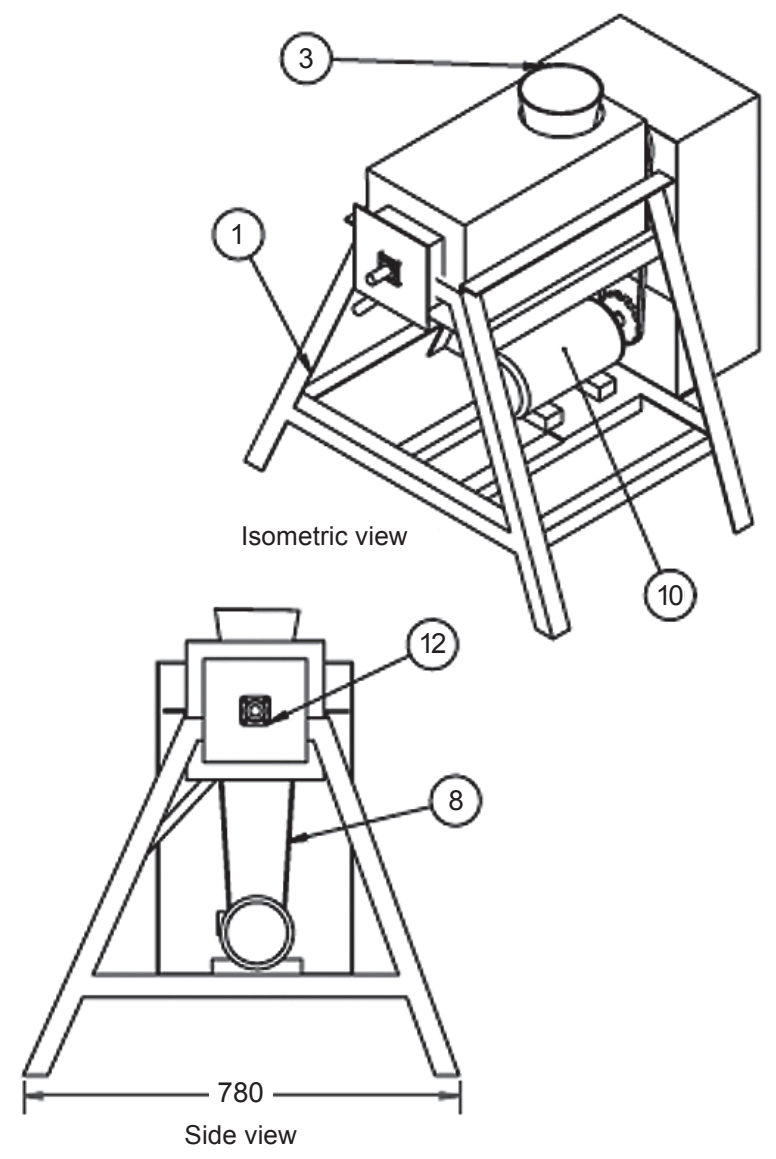

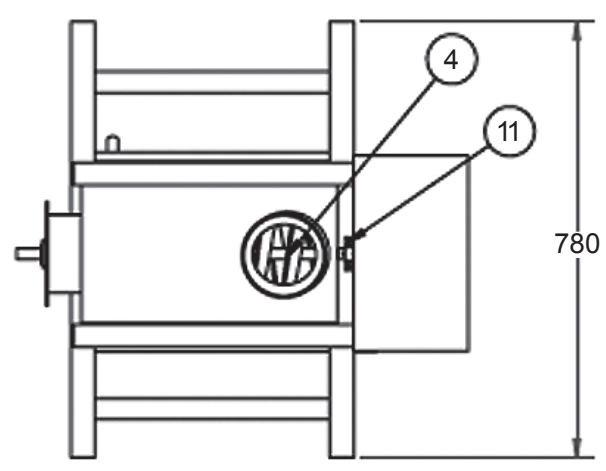

Top view

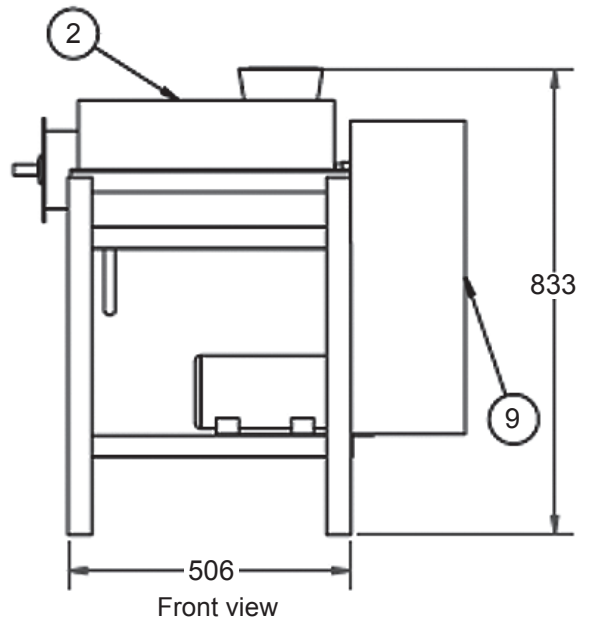

Figure 5. Production drawing of machine components (isometric and orthographic views).

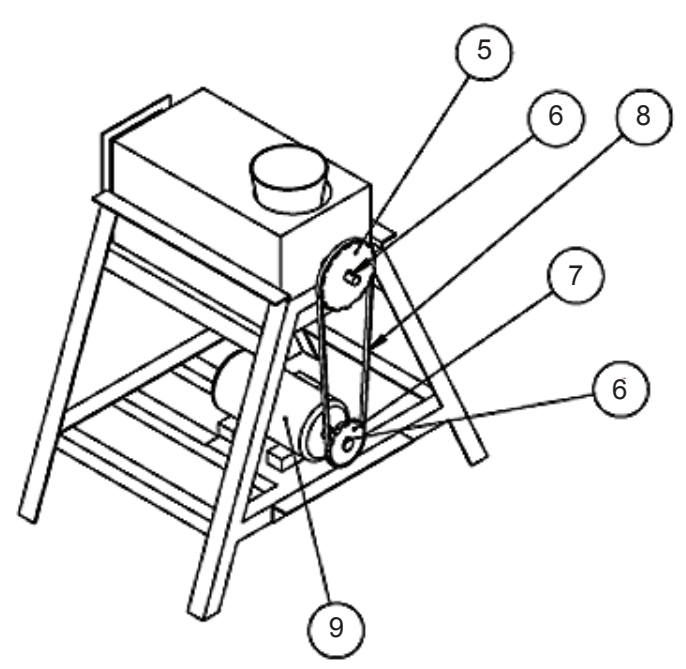

\begin{tabular}{|c|c|c|c|}
\hline Item No. & Part number & Description & Quantity \\
\hline 1 & Frame & Stainless steel $304,40 \times 40 \times 3 \mathrm{~mm}$ & 1 \\
\hline 2 & Cover & $\begin{array}{c}\text { Stainless steel } 304,3 \mathrm{~mm} \text { thick } \\
\text { sheet }\end{array}$ & 1 \\
\hline 3 & $\begin{array}{l}\text { Oil extraction } \\
\text { cylinder }\end{array}$ & $\begin{array}{c}\text { Stainless steel } 304, \text { sieve hole dia } 2 \\
\text { mm, thickness }-3 \mathrm{~mm}\end{array}$ & 1 \\
\hline 4 & Screw shaft & $20 \mathrm{~mm}$ dia shaft & 1 \\
\hline 5 & Larger sprocket & Cast iron (90 teeth) & 1 \\
\hline 6 & Key & Cast iron, $5 \times 5 \mathrm{~mm}$ & 2 \\
\hline 7 & Small sprocket & Cast iron (12 teeth) & 1 \\
\hline 8 & Chain & Plain carbon steel, length $2280 \mathrm{~mm}$ & 1 \\
\hline 9 & Motor & $1 \mathrm{HP}$ (3 phase, geared) & 1 \\
\hline 10 & Bearing & Pillow block & 1 \\
\hline 11 & Bearing2 & $\begin{array}{c}4 \text { bolt square flange mounted ball } \\
\text { bearing }\end{array}$ & 1 \\
\hline
\end{tabular}

Figure 6. Part of machine components with part and materials list. 


\section{Machine Performance}

Results of machine performance of the two extraction methods are shown in Table 1.

TABLE 1. PERFORMANCE EVALUATION OF THE EXTRACTION METHOD

\begin{tabular}{lcc}
\hline Parameter (\%) & $\begin{array}{c}\text { Semi-mechanised } \\
\text { motorised method }\end{array}$ & Traditional method \\
\hline OER & $16.20 \mathrm{a} \pm 0.20$ & $13.53 \mathrm{~b} \pm 0.46$ \\
OEE & $77.13 \mathrm{a} \pm 0.95$ & $64.44 \mathrm{~b} \pm 2.20$ \\
MDE & $81.70 \mathrm{a} \pm 0.36$ & $73.13 \mathrm{a} \pm 2.02$ \\
OEL & $18.30 \mathrm{a} \pm 0.36$ & $24.76 \mathrm{~b} \pm 1.04$ \\
\hline
\end{tabular}

Note: Each value is expressed as mean \pm standard deviation $(n=3)$. Means with different letters within rows are significantly $(p \leq 0.05)$ different.

OER - oil extraction ratio, OEE - oil extraction efficiency, MDE - material discharge efficiency, OEL - oil extraction loss.

There were significant differences $(p \leq 0.05)$ between OER, OEE and OEL of the two methods of extraction while MDE of the two extraction methods did not show a significant difference. The motorised extraction method using the constructed palm oil extractor had the greater mean values of OER, OEE and MDE of $16.02 \%, 77.13 \%$ and $81.70 \%$, respectively (Table 1). This was due to the improvement in the design of the machine as compared to the traditional extraction machine that is in existence and this led to the improvement and increase in these efficiencies which was the objective of the design. The mean OEL was greater for the traditional extraction method $(24.76 \%)$. This was due to the mode of extraction that involved four people operating the vertical screw press that largely depended on their working modes and individual energies that cannot be mechanically controlled as it was the case with the designed motorised extractor whose design parameters were predetermined.

\section{Physio-chemical Quality Parameters}

The physio-chemical quality parameters of the two extraction methods are presented in Table 2.

Results for FFA of the oil samples show a significant $(p \leq 0.05)$ difference between the means, with the traditional extraction method having a higher value $(6.86 \%)$ than the semi-mechanised motorised extraction method. The IV and SV values for the two methods did not show a significant ( $p>0.05)$ difference between the means, while in both oil samples of the extraction methods, the PV was not detected.

The FFA value of $2.47 \%$ for the semi-mechanised method is below the maximum limit of $5 \%$ for virgin extracted palm oil (Alimentarius, 1994) which indicates good quality of this oil sample while the FFA value of $6.86 \%$ for the traditional method is above the maximum limit of $5 \%$ which indicates poor quality of this oil sample. The FFA results of this study are comparable to those of Ngando et al. (2011) who reported \% FFA of $6.39 \%$ for traditional method and 5\%-10.36\% for semi-mechanised method. However, the results of this study are below those reported by Amata and Ozuor (2013) of $15.97 \%$ for the traditional method and $13.70 \%$ for the semi-mechanised method while the value of $6.86 \%$ for the traditional method is greater than that reported by Onwuka and Akaerue (2006) of 2.75\% by traditional extraction method. The $2.47 \%$ FFA for this study is below that reported by Ohimain et al. (2013) of $8.43 \%$ for semi-mechanised processor in Bayelsa state Nigeria. FFA concentration is the most widely used criterion for determining the quality of palm oil and must not exceed $5 \%$, presence of FFA in palm oil is an indicator of impairment of the quality of the oil (Amata and Ozuor, 2013). Since the oil extracted by both methods in this study was from the same variety (Tenera) and subjected to the same conditions before laboratory analysis (same shelf-life of $48 \mathrm{hr}$ after extraction), it indicates that the differences in FFA values were brought about by the method of extraction.

The IV of 36.65 and 43.62 for semi-mechanised and traditional extraction methods respectively were both below the maximum limit of 55 (Alimentarius, 1994). This implies that in both oil samples, there were lower levels of deterioration, unsaturation as well as susceptibility to oxidative rancidity. The values for this study are comparable to those of Akubor and Ogu (2012) of 30.4-42.8 and those of Onwuka and Akaerue (2006) of 38.442.8 but below those reported by Agbaire (2012) of 55.55-53.66 and that of Ohimain et al. (2013) of 51.17. Much as there was no significant $(p>0.05)$ difference in the IV of the oil samples, semimechanised method had a lower value implying that its oil was of a higher quality as compared to that of the traditional method.

TABLE 2. PHYSIO-CHEMICAL QUALITY PARAMETERS OF OIL EXTRACTED BY THE TWO DIFFERENT METHODS

\begin{tabular}{lcc}
\hline Parameter & $\begin{array}{c}\text { Semi-mechanised } \\
\text { motorised method }\end{array}$ & $\begin{array}{c}\text { Traditional } \\
\text { method }\end{array}$ \\
\hline FFA $(\%$ of oleic acid $)$ & $2.47 \mathrm{a} \pm 0.35$ & $6.86 \mathrm{~b} \pm 0.68$ \\
$\mathrm{IV}$ & $36.65 \mathrm{a} \pm 0.30$ & $43.62 \mathrm{a} \pm 4.52$ \\
$\mathrm{SV}\left(\mathrm{mg} \mathrm{KOH} \mathrm{g}^{-1}\right)$ & $193.74 \mathrm{a} \pm 9.39$ & $182.39 \mathrm{a} \pm 8.32$ \\
$\mathrm{PV}\left(\mathrm{Meq} \mathrm{O}_{2} \mathrm{~kg}^{-1}\right)$ & $\mathrm{ND}$ & $\mathrm{ND}$ \\
\hline
\end{tabular}

Note: Each value is expressed as mean \pm standard deviation $(n=3)$. Means with different letters within rows are significantly ( $\mathrm{p} \leq 0.05)$ different. ND - not detected. FFA - free fatty acids, IV - iodine value, SV - saponification values, $\mathrm{PV}$ - peroxide value. 
The SV of 193.74 and 182.39 for semi-mechanised and traditional methods respectively were both below the maximum limit of 209 given by Alimentarius (1994). The SV is an indicator of the molecular weights of the triglycerides and it is inversely proportional to the length of fatty acids (Muhammad et al., 2011). This can be justified by the results of this study where the traditional method had a lower SV (182.39) but a higher value of FFA $(6.86 \%)$ than the semi-mechanised method. The SV of 193.74 for the semi-mechanised method is comparable to that of Ohimain et al. (2013) of 192.05 and that of Akubor and Ogu (2012) of 191-235 while the SV for the traditional method of 182.39 is comparable to that of Onwuka and Akaerue (2006) of 107-251. However, the results of this study are below those reported by Agbaire (2012) of 195.76-198.75.

For both the oil samples extracted by the two methods, the PV was not detected implying that no spoilage had taken place in these oil samples in terms of oxidation under storage and rancidity occurring under mild conditions (Agbaire, 2012). PV assesses the quality of cooking oils through the measurements of the amount of lipid peroxides and hydro-peroxides formed during initial stages of oxidative degradation (Ngando et al., 2013). The method of extraction therefore did not have an effect on the PV of the final oil product.

\section{CONCLUSION}

Results from this study indicated that the semimechanised method of oil extraction had greater efficiencies in terms of oil yield, oil extraction efficiency and material discharge efficiency in comparison to the traditional extraction method. In terms of the physio-chemical parameters, oil extracted by the semi-mechanised motorised method had better quality parameters with its FFA, IV and SV all being below the maximum limits given by Alimentarius (1994). The FFA value for the traditionally extracted oil was above the maximum limit which indicated a low quality in this oil samples while the IV and SV were below the maximum limits though greater than those for the semimechanised method which justifies that the method of oil extraction greatly affects the quality of the oil produced. The production cost of the machine (USD 1142 ) is affordable to smallholder palm oil farmers and hence, adopting this technology makes them competitive on the market due to the high quantity and quality of the produced oil.

\section{REFERENCES}

Agbaire, P O (2012). Quality assessment of palm oil sold in some major markets in Delta State, Southern
Nigeria. African J. Food Science and Technology, 3(9): 223-226.

Akubor, P and Ogu, G I (2012). Quality attributes of fresh palm oil produced from selected communities around Anyigba, Kogi State, Nigeria. Nigerian J. Nutritional Sciences, 33(1): 12-17.

Alimentarius, C (1994). Joint FAO/WHO Food Standards Programme. Codex Committee on Methods of Analysis and Sampling: $19^{\text {th }}$ Session, Budapest, Hungary. Criteria for Evaluating Acceptable Methods for Evaluating Acceptable Methods for Codex Purposes. http: / / www.fao.org/ tempref/codex / Meetings / CCEXEC/CCEXEC62/ ex62_05e.pdf, accessed on 22 November 2016.

Amata, I A and Ozuor, E (2013). The effect of different processing methods on the quality of crude palm oil (CPO) in Delta North Agricultural zone of Delta State, Nigeria. J. Environmental Issues and Agriculture in Developing Countries, 5(1): 19-24.

Anebi, J G; Umogbai, V J and Bako, T (2014). Design and construction of a soyabean oil extracting machine. Asian J. Science and Technology, 5(10): 606611.

Aremu, A K and Ogunlade, C A (2013). Development and performance evaluation of an extractor for removing oil from soaked kenaf bast and core. Int. J. Advanced Research Vol. 1(4): 196-201.

Azodo, P A; Hasan A B; Ezenwa, J and Oghan, P U (2013). Design and fabrication of motorized hydraulically operated palm oil press. The Pacific J. Science and Technology, 14(1): 79-88.

Hall, A S; Holowenko, A R and Laughlin, H G (1961). Theory and Problems of Machine Design. New York: McGraw-Hill. 344 pp.

IFAD (2010). Vegetable Oil Development Project. Interim Evaluation, Report No. 2195-UG. http:// www.ifad.org > documents > vodp.pdf, accessed on 19 January 2016. p. 193-209.

Khurmi, R S and Gupta, J K (2005). A Text Book of Machine Design. Eurasia Publishing house (PVT) Ltd., Russia. p. 576-586.

Kukeera, T; Banadda, N; Tumutegyereize, P; Kiggundu, N and Asuman, N R (2015). Extraction, quantification and characterization of oil from pumpkin seeds. Int. J. Agricultural and Biological Engineering, 8(1): 98-102.

Mahmud, A; Rehrig, M and Hills, G (2010). Improving the livelihoods of palm oil smallholders: 
The role of the private sector. FSG Social Impact Advisors for the World Bankgroup, Washington, DC. http: / / www.fsg.org/publications / improvinglivelihoods-palm-oil-smallholders, accessed on 17 March 2016.

Moses, D M (2014). Performance evaluation of continuous screw press for extraction of soybean oil. Amer. J. Science and Technology, 1(5): 238-242.

Mrema, G C and McNulty, P B (1985). Mathematical model of mechanical oil expression from oil seeds. J. Agricultural Engineering Research, 31(5): 361-370.

Muhammad, N; Bamishaiye, E; Bamishaiye, O; Usruan, L; Salawu, M; Nafiu, N and Olayede, O (2011). Physiochemical properties and fatty acid composition of Cyperus escalentus (Tiger Nut). Tuber oil. Biores Bull, 5: 51-54.

Ngando, E G F; Mpondo, M E A and Ewane, M A (2013). Some quality parameters of crude palm oil from major markets of Douala, Cameroon. African J. Food Science, 7(12): 473-478.

Ngando, E G F; Mpondo, E A; Dikotto, E E L and Koona, P (2011). Assessment of the quality of crude palm oil from smallholders in Cameroon. J. Stored Products and Postharvest Research, 2(3): 52-58.

Nsiah, S A; Zu, A C S and Nimoh, F (2012). A technological and financial assessment of small scale palm oil production in Kwaebibrem District, Ghana. J. Agricultural Science, 4(7): 111-120.

Ohimain, E I; Izah, S C and Fawari, A D (2013). Quality assessment of crude palm oil produced by semi-mechanized processors in Bayelsa State, Nigeria. Discourse J. Agriculture and Food Sciences, 1(11): 171-181.

Okogeri, O and Otika, N F (2014). Quality parameters of crude palm oil obtained by traditional processing techniques. Department of Food Science and Technology. Ebonyi State University. http: / www. cibindia.in / 16052 / processing-of-crude-palm-oil, accessed on 24 January 2016.

Olaniyan, A M; Yusuf, K A; Wahab, A L and Afolayan, K O (2012). Design, development and testing of a screw press expeller for palm kernel and soybean oil extraction. Post-harvest, Food and Process Engineering. Int. Conference of Agricultural EngineeringCIGR-AgEng 2012. Valencia, Spain. p. 1748.

Onwuala, A P; Akubuo C O and Ahaneku, I E (2006). Fundamentals of Engineering in Agriculture. Lagos: Immaculate Publications Ltd. p. 259-262.

Onwuka, G I and Akaerue, B I (2006). Evaluation of the quality of palm oil produced by different methods of processing. Research J. Biological Sciences, 1(1-4): 16-19.

Osei-Amponsah, C; Visser, L; Adjei-Nsiah, S; Struik, P C; Sakyi-Dawson, O and Stomph, T J (2012). Processing practices of small-scale palm oil producers in the Kwaebibirem District, Ghana: A diagnostic study. NJAS-Wageningen J. Life Sciences, 60: 49-56.

Owalarafe, O K; Osunleke, A S and Oyebamiji, B E (2007). Effect of hydraulic press parameters on crude palm oil yield. Int. Agrophysics, 21: 285-291.

Pearson, D (1976). The Chemical Analysis of Foods. $7^{\text {th }}$ edition. Longman Group Ltd. p. 626-641.

Poku, I (2002). Small scale palm oil processing in Africa. FAO Agricultural Services Bulletin 148. Food and Agricultural Organisation of the United Nations. Rome. 56 pp.

Razali, M H; Ssomad, A M; Halim, M A and Roslan, $S$ (2012). A review on crop plant production and ripeness forecasting. Int. J. Agriculture and Crop Sciences, 4(2): 54-63.

Shigley, J E and Mischeke, C R (2001). Ch. 18. Mechanical Engineering Design. $6^{\text {th }}$ Edition. McGrawHill Higher Education. New York. p. 933-951.

Tarmizi, A H A; Razali, I and Kuntom, A (2016). Effect of frying on the palm oil quality attributes - A review. J. Oil Palm Res. Vol. 28(2): 143-153.

WorldGrowth (2011). The economic benefit of palm oil to Indonesia (February). http: / / www.scirp.org, accessed on 13 February 2016.

Wortmann, C S and Sones, K R (2017). Fertilizer Use Optimization in Sub-Saharan Africa. CABI. p. 193-209. 